\title{
ОСОБЛИВОСТІ СЕМАНТИКИ ФРАЗЕОЛОГІЗМІВ ІЗ КОМПОНЕНТОМ-НАЗВОЮ ЯВИЩА ПРИРОДИ
}

Качайло К. А. Особливості семантики фразеологізмів із компонентом-назвою явища природи.

У статті розглянуто особливості семантики фразеологізмів із компонентомназвою явища природи, використаних у перекладах Миколи Лукаша. Описано явище багатозначності, синонімічні та антонімічні відношення досліджуваних фразем, а також фразеологічну варіативність.

Ключові слова: семантика, фразеологізм, синонімія, антонімія, фразеологічна варіативність.

Качайло К. А. Особенности семантики фразеологизмов с компонентомназванием явления природы.

В статье рассмотрены особенности семантики фразеологизмов с компонентомназванием явления природы, использованных в переводах Николая Лукаша. Описано явление многозначности, отношения синонимии и антонимии исследуемых фразем, а также фразеологическая вариативность.

Ключевые слова: семантика, фразеологизм, синонимия, антонимия, фразеологическая вариативность.

Kachaylo K. A. The features of semantics phraseology with the component the name of natural phenomenon.

The features of semantics phraseology with the component- the name of natural phenomenon are used in Mykola Lukash's translations are considered in this article. The phenomenon of polisemanticy, synonymous and antonymous relations of investigated phraseological units and phraseological variation are described.

Key words: semantics, phraseological unit, synonymy, antonymy, phraseological variation. 
Фразеологічні одиниці, на думку сучасних мовознавців, увібрали в себе історичні події й соціальне життя, вирізняють найменші порухи нашого серця, розказують про неосяжний світ людських почувань, вражають точністю асоціацій між природою, звичайними життєвими фактами і людською поведінкою, нашими емоціями і вчинками.

Підгрунтя вивчення фразеологічних одиниць було закладене в працях Ф. І. Буслаєва, О. О. Потебні, I. І. Срезневського, О. О. Шахматова. Їх спадщину розвинули В. Л. Архангельський, О. М. Бабкін, О. І. Білодід, В. В. Виноградов, В. П. Жуков, Б. О. Ларін, В. М. Мокієнко, О. І. Молотков, М. М. Шанський та інші вчені.

Деякі теоретичні та практичні аспекти української фразеології були предметом монографічного опису в працях Л. Г. Авксентьєва, М. Ф. Алефіренка, В. С. Калашника, М. П. Коломійця, А. Івченка, В. Н. Телії, Л. Г. Скрипник, В. Д. Ужченка, Л. В. Мельника та інших.

За даними сучасних досліджень, фразеологізми відображають в основному життя людини. Лише незначна кількість виразів характеризує тваринний і рослинний світ, а також деякі явища природи.

Мета статті - вивчити семантичні особливості українських фразеологізмів з компонентом-назвою явища природи, які використані у перекладах Миколи Лукаша.

За даними фактологічного матеріалу, зібраного за словникомдовідником, який уклали О. І. Скопненко та Т. В. Цимбалюк [3], у перекладах Миколи Лукаша зафіксовано більше двохсот фразеологізмів, які містять у собі лексеми, що є назвами явищ природи. Статистичні підрахунки показали, що за кількістю на першому місці - фраземи із лексемою земля (19 \% від усіх проаналізованих мовних одиниць), на другому - із небо $(17 \%)$, на третьому - 3 вода (14 \%). Далі в порядку спадання йдуть фразеологізми $з$ іншими найменуваннями явищ природи: вітер (10 \%), хмара (8,5 \%), грім (6,5\%), сонще (5\%), вогонь (5\%), лід (3\%), море (3\%), повітря (2 \%), дощ (2 \%), мороз (1\%), блискавка (1 \%), блискавиия (0,5\%), буря (0,5\%), вихор (0,5\%), джерело (0,5\%), роса (0,5\%), туча $(0,5 \%)$.

Фразеологізми із лексемою земля передають найрізноманітніші значення: бути під землею (171)* «померти»; земля не хоче носити (171) «становище у когось безвихідне, скрутне»; зійти в чужу землю (171) «піти у краї, далекі від рідної домівки»; змести із землі (171) «знищити, ліквідувати щось»; зрівняти із землею (171) «зруйнувати повністю, знищити вщент»; ладний провалитися крізь землю (171) 
«бажання якомога швидше звідкись зникнути»; лишити землю (171) «померти»; міряти землю ногами (171) «мандрувати, блукати по світах»; міџно держатися на землі (172) «бути впевненим у своїх діях, учинках»; не бачити ані землі, ні неба (172) «нічого не помічати навкруги себе»; піти землю їсти (172) «умерти»; по всій землі годi шукати (172) «про щось надзвичайно рідкісне»; рівняти з землею (172) «знищувати вщент»; ударити об землю (172) «зазнати біди, лиха, але не зважати на це»; хай його із землею змісить! (172) «лайливе побажання смерті, загибелі»; хоч би й під землю залізти (172) «щезнути, перестати існувати; заховатися якнайдалі, причаїтися»; мов крізь землю провалитися (172) «бажання щезнути, перестати існувати від сорому або страху»; мов не черкаючи землі (172) «легко, швидко»; немов крізь землю провалитися «раптово, безслідно зникнути»; неначе з-під землі вирости (172) «несподівано з'явитись де-небудь»; як землі до неба (172) «дуже далеко»; віддати тіло землі (465) «поховати, похоронити когонебудь»; закопувати талант у землю (462) «не використовувати, не розвивати свої здібності, занедбувати своє обдарування»; згладитися 3 лиця землі (226) «зникнути, бути знищеним»; змітати з лиця землі (226) «знищувати повністю»; знищити з лищя землі (226) «жорстоко розправитися 3 ким-небудь»; кинути лихом об землю (224) «забути біду, горе, не журитися, не втратити надії на краще»; літа прибивають к землі (230) «Хто-небудь старий, відчуває наближення своєї смерті»; між небом $і$ землею (265) «безперервно, невпинно»; небо $i$ земля (265) «щось протилежне, не схоже між собою»; розходитись, мов небо $і$ земля (266) «дуже відрізнятися один від одного або віддалятися»; рити носом землю (276) «ретельно шукати когонебудь»; спустити очі в землю (304), уриватися/уритися очима в землю (306), устромити очі в землю, утупити очі в землю, утупитися очима в землю (307) «не дивитися прямо на кого-небудь, потупити погляд»; ударити журбою об землю (162) «забути біду, горе, не журитися, не втратити надії на краще»; узятися землею (172) «зітліти».

Фраземи із лексемою небо представляють таку семантику: вихваляти аж до неба (265) «дуже, надмірно хвалити когось»; до самого неба (265) «дуже високо»; добратися до неба (265) «випробувати всі можливі й неможливі засоби для досягнення чогось»; доп'ястися до неба (265) «запаніти»; здійматися до неба (265) «дуже високо підніматися»; небо дарувало (265) «судилося що-небудь (c) К. А. Качайло, 2012. 
комусь»; небо з'єднало (265) «судилося бути разом»; небо зласкавилось (265) «щось склалося сприятливо, хоч для цього начебто не було передумов»; небо не судило (265) «щось не склалося, не здійснилося в житті»; небо ниспослало (265) «щось склалося, здійснилося в житті»; небо одвернулося (265) «обставини змінилися на гірше, почало не щастити»; небо пошле (265) «щось або хтось з'явиться, прийде»; небо судило (265) «щось склалося, здійснилося у когось певним чином»; падати з неба (266) «діставатися дуже легко, без труднощів»; під голим небом (266) «надворі, без усякої покрівлі»; під ясним небом (266) «відкрито, не приховуючись»; прихиляти / прихилити небо (266) «робити для когось усе, навіть неможливе»; просто неба (266) «надворі, без усякої покрівлі»; упасти з неба (266) «з'явитися раптово, несподівано»; хай мене скарає небо (266) «заприсягання щодо достовірності сказаного»; немовби неба прихилили (266) «зробити для когось усе, навіть неможливе; відчути велику радість, задоволення»; виріс до неба, дурний як треба (266) «про високу, але розумово обмежену людину»; бачить Бог із неба, чого кому треба (30) «кожна людина має в житті тільки те, що їй судилося долею»; душа злетіла на небо (143) «хтось помер»; краще синиця в жмені, ніж журавель у небі та краще синиця в жмені, чим журавель в небі (415) «краще мати хоч що-небудь зараз, ніж сподіватися на ліпше»; мов грім з неба (96) «дуже голосно»; між небом $i$ землею (265) «безперервно, невпинно»; небо $i$ земля (265) «щось протилежне, не схоже між собою»; наче грім з ясного неба (96) «несподівано, раптово, зненацька»; розходитись, мов небо $i$ земля (266) «дуже відрізнятися один від одного або віддалятися»; не бачити ані землі, ні неба (172) «нічого не помічати навкруги себе»; не дістати, як зірок з неба (175) «абсолютно неможливо що-небудь зробити»; хвала небові святому (494) «подяка за щасливе вирішення якихось проблем»; як землі до неба (172) «дуже далеко». Отже, лексема небо в одних випадках є справді найменуванням явища природи, а в інших уособлює вищі сили, Божу волю або й самого Бога.

Далі за кількістю йдуть фразеологічні одиниці зі словом вода: багато води втекло (53) «минуло багато часу»; вивести на чисту воду (53) «викрити чиюсь непорядність, нечесність; розказати правду про щось, розкрити істину»; вода не освятиться (без когось) (53) «про непосидющу людину, що встигає побувати в різних місцях, узяти участь у багатьох справах, без присутності якого нічого не відбувається»; водою не розлити (53) «не розлучити, не роз'єднати 
кого-небудь»; каламутити воду (53) «вносити розлад, неспокій»; не багато води утекло (53) «минуло не дуже багато часу з якоїсь пори»; небагато води втекло (53) «не дуже давно щось було»; не братися й за холодну воду (53) «нічого не робити, байдикувати»; не взятися й за холодну воду (53) «нічого не зробити»; піти за водою (53) «пропасти, марно зникнути»; пливти за водою (53) «пасивно підкорятися обставинам, нічого не роблячи для поліпшення свого становища»; товкти воду в cmуni (54) «робити що-небудь непотрібне, марно гаяти час»; чимало води втекло (54) «минуло багато часу з якоїсь пори»; мов води в рот набрати (54) «затято мовчати; не мати бажання говорити про щось або з кимось»; мов у воду впасти (54) «безслідно, раптово зникнути»; немов вода (54) «дуже швидко»; сплисти як вода (54) «дуже швидко минути»; як вода вмила (когось) (54) «хто-небудь швидко, раптово зник»; як воду (54) «у великій кількості або легко»; як із води (54) «дуже швидко»; не зарікайся пити води (54) «застереження від самовпевненості й категоричності в думках і діях»; долити до окропу холодної води (308) «заспокоїтися, угамувати якінебудь почуття»; $i$ кінщі у воду (192) «не залишити ніяких слідів злочину»; із личка води не пити (228) «у житті не все вирішує врода»; набрати в рот води (374) «нічого не сказати, замовкнути»; не зарікайся з криниці воду пити (207) «не сварися з людьми, бо в майбутньому ти можеш шукати підтримки в них»; пірнути з головою у воду (83) «повністю, цілком віддатися якійсь справі, заняттю»; nіти в огонь $i$ воду (286) «зазнати всіляких випробувань, виявитися дуже спритним, мужнім, витривалим»; утопити в ложці води (231) «завдати великих прикростей, згубити когось 3 ненависті, викликаної дрібницями»; як двi краплі води (206) «надзвичайно схожий, однаковий»; як риба без води (361) «почуватися погано, вимушено, некомфортно».

Фразеологічні одиниці з лексемою вітер представлені такими виразами: бігти під три вітри (50) «іти геть, куди завгодно»; вітер y голові (50) «бути легковажним, несерйозним»; вітер у голові ганяє (50) «бути легковажним, несерйозним»; гнатися за вітром (50) «шукати щось примарне, нереальне»; звідки вітер віє (50) «що виступає орієнтиром для дій, учинків»; $i$ вітер не подми (50) «про когось дуже пещеного, пихатого»; летіти, не кажи ти вітер! (50) «дуже швидко бігти»; мчати вітром (50) «дуже швидко бігти»; на вітер (50) «марно»; на всі вітри (50) «куди завгодно»; переміниться вітер фортуни (50) «зміниться чия-небудь доля або перебіг подій»; 
плисти проти вітру (50) «діяти всупереч усталеним поглядам, традиціям»; плювати проти вітру (51) «діяти нерозсудливо, собі на шкоду»; розвіюватися вітром (51) «губитися, безслідно зникати»; розвіюватися по вітру (51) «губитися, зникати, пропадати»; шукай вітру в полі (51) «даремно шукати кого-небудь, безрезультатно»; яким вітром принесе (51) «про невідому причину появи»; мов вітер (51) «дуже швидко»; мов вітер здув (51) «хтось раптово зник»; мов вітром здуло (51) «хтось несподівано і безслідно зник»; як вітром змело (51) «хтось або щось раптово, несподівано зникло»; дме ходовий вітер напинаймо ж вітрила (51) «треба скористатися слушною нагодою».

Наступну групу складають фразеологічні одиниці зі словом хмара: аж до хмар (500) «дуже високо»; аж у хмари вдарило (500) «інтенсивність якоїсь дії»; аж у хмари зайти (500) «здійснити щось нереальне, нездійсненне»; за хмарами (500) «подумки у мріях, відірвано від реального життя»; залітати за хмари (500) та зариватися в хмари (500) «мріяти про щось нереальне, недосяжне»; літати в $\boldsymbol{x м a p a x ~ ( 5 0 0 ) ~ « с п р и и ̆ м а т и ~ д і и ̆ с н і с т ь ~ н е р е а л ь н о , ~ н а і ̈ в н о » ; ~ л і т а т и ~ в ~ х м м а р и ~}$ (500) «нереально сприймати дійсність, бути мрійником»; мандрувати поза хмари (500) «мріяти про щось нереальне, недосяжне»; нестися аж до хмар (500) «бути про себе високої думки, пихато поводитися»; облягти хмарою (500) «оточити великою кількістю»; піднестися над хмари (500) «дуже високо піднятися»; рватися аж до хмари (500) «бути спрямованим до вищих сил»; зважати, як на торішні хмари (500) «зовсім не реагувати на когось»; пам'ятати, як за торішні хмари (501) «зовсім не пам' ятати щось»; як осіння хмара (501) «невесело»; як темна хммара (501) «похмурий, невеселий, сумний»; як хмара б’ 6 (501) «надзвичайно велика кількість, дуже багато».

П'ятнадцять фразем містять у собі лексему грім, наприклад: грім би його побив! (96) «виражає крайнє незадоволення, побажання комусь нещастя»; метати громи $i$ блискавки (96) «говорити роздратовано, погрожувати, обвинувачувати»; грім його скарай! (96) «виражає крайнє незадоволення, побажання комусь нещастя»; грім мене вбий! (96) «заприсягання в правдивості своїх слів»; грім убий! (96) «виражає незадоволення ким-небудь, побажання йому нещастя»; нехай мене вб'є zрім! (96) «заприсягання в правдивості своїх слів, запевнення у чомунебудь»; побив би ӥх грім! (96) «виражає незадоволення чим-небудь»; спалив би вас грім небесний! (96) «виражає незадоволення ким-небудь»; ударить грім (96) «що-небудь трапиться раптово, несподівано, зненацька»; мов грім 3 
неба (96) «дуже голосно»; наче грім (96) «несподіваний, раптовий»; наче грім з ясного неба (96) «несподівано, раптово, зненацька»; ніби вражений громом (97) «раптово, несподівано, зненацька»; як грім (97) «раптом, дуже швидко»; не страшно ні тучі ні грому (473) «безстрашний хтось».

Іменник сонце зафіксований у фразеологізмах 3 такими значеннями: як сонце в місяия світла позичить (446) «ніколи»; хто сонце засипає, той дневі не рад буває (446) «хто пізно встає, той мало встигає зробити за день»; буває дощ $i$ сонце заразом (125) «неприємності йдуть поряд 3 веселощами»; до схід сонця (459) «дуже рано, перед світанком»; мов муха на сонці (257) «сердитий, уїдливий, злий»; мов пшениця на сонці (353) «яскраво-жовте щось»; не бачити за пилиночкою сонця (324) «не помічати за дрібним, частковим загального, основного»; танути, мов сніг на сонці (443) та танути, як сніг на сонці (443) «швидко втрачати фізичну й душевну силу»; не бачити під зорею і сонцем (179) «щось дивовижне, чого не бачили».

Лексема вогонь наявна в усталених конструкціях: горіти вогнем (52) «дуже боліти»; днем з вогнем пошукати (107) «не можна розшукати кого-небудь, навіть докладаючи великих зусиль»; додати вогню до вогню (52) «погіршити становище, ускладнити його»; крізь вогонь $i$ меч (52) «через усі перешкоди й небезпеки»; пекти вогнем (52) «мучити, непокоїти»; піти вогнем (52) «згоріти»; поміж двох вогнів (52) «бути у становищі, коли небезпека загрожує з двох боків»; прикладати вогню до печеного (53) «погіршувати становище, ускладнювати що-небудь чимось»;танути, мов лід на вогні (228) «дуже швидко зникати».

Далі за кількістю йдуть фразеологічні одиниці зі словами лід та море:

1) загнати на лід (228) «поставити кого-небудь у безвихідне, скрутне становище»; просити печеного льоду (228) «вимагати чогось неможливого»; розтопити лід (228) «ліквідувати холодність, вороже ставлення до когось»; шукати печеного льоду (228) «витрачати час на пошуки того, що не існує»; танути, мов лід на вогні (228) «дуже швидко зникати»; як лід (228) «дуже холодний»; серце наче лід (411) «байдужість до когось»;

2) житейське море (256) «життя з його турботами, проблемами тощо»; море по коліна (256) «нічого не страшно, ніщо не лякає»; проливати море сліз (256) «дуже гірко плакати»; розлити море сліз (256) «гірко заплакати»; чисте море (256) «частина моря, розміщена якнайдалі від узбережжя»; y голові думу, як на морі шуму (88) «Глибокі емоційно напружені роздуми»; печерувати грушки в морі (99) «шукати чуттєвих насолод».

() К. А. Качайло, 2012. 
Фраземи зі словами повітря та дощ складають невеликі групи:

1) вилетіти в повітря (331) «розлетітися на шматки від вибуху»; висадити в повітря (331) «зруйнувати за допомогою вибухових пристроїв»; повно повітря в голові (332) «хтось легковажний, непостійний»; полетіти в повітря (332) «вибухнути»; потрясти повітря (332) «голосно сказати; закричати»;

2) буває дощ і сонце заразом (125) «неприємності йдуть поряд 3 веселощами»; з дощу та під ринву (125) «від однієї неприємності до іншої, ще більшої»; посипатися дощем (125) «з'явитися у дуже великій кількості»; сіяти дощем (125) «давати у великій кількості щонебудь»; виглядати, як дощу в травні (125) «дуже хотіти побачити когось, зустрітися із кимось».

Небагато фразеологізмів із лексемами мороз та блискавка:

1) аж морозом сипонуло поза спиною (256) «з переляку виникло неприємне відчуття холоду»; проймати морозом (256) «викликати відчуття холоду, тремтіння від великого хвилювання, переживань»; тремтіти, як у мороз сирота (256) «дуже сильно змерзнути»;

2) облетіти блискавкою (22) «дуже швидко поширитися (про чутку, новину)»; як блискавка (22) «дуже швидко, миттєво»; метати громи $і$ блискавки (96) «говорити роздратовано, погрожувати, обвинувачувати».

Іменник блискавищя зафіксований у двох випадках, а лексеми буря, вихор, джерело, роса, туча наявні у поодиноких фразеологічних одиницях: кресати з очей блискавцці (294) «кидати погляд, виражаючи почуття сильного гніву, незадоволення, роздратування»; як блискавиця (22) «дуже швидко»; бушувати як буря (33) «високий ступінь вияву почуттів»; як вихор (41) «дуже швидко»; забити джерелом (108) «виявитися на всю силу, у великій мірі»; перегнати через росу (374) «примусити кого-небудь переживати, плакати; дошкулити комусь»; не страшно ні тучі ні грому (473) «безстрашний хтось».

Отже, фразеологізми з компонентом-назвою явища природи, використані у перекладах Миколи Лукаша, передають як загальновідомі значення, так і виявляють авторську творчість, що виражається в розширенні або звуженні семантики окремих фразем. «Чи треба дивуватися: деякі його переклади образно й емоційно багатші за оригінал. I йде воно як від Лукашевого великого таланту, так і від лексичного, фонетичного, фразеологічного багатства української мови, що іiі Микола Лукаш знав глибоко і всеосяжно, в усіх явних і прихованих могутностях і нюансах» [3, с. 713]. 
Важливо зазначити, що деякі досліджувані усталені конструкції вступають між собою у відношення синонімії. Науковці стверджують, що фразеологізми-синоніми об' єднані спільним (близьким) значенням, однак у їх основі лежать різні образи, що відчутно спричинює їх відмінність у відтінках значення. Різницю в образах, що лягли в основу внутрішньої форми, виразно демонструють фразеологічні одиниці, які розкривають поняття «дуже швидко», наприклад: як блискавиия (22), як вихор (41), мчати вітром (50), мов вітер (51), немов вода (54), сплисти як вода (54), як із води (54), як грім (97).

Значення «виражати почуття сильного гніву, незадоволення, роздратування» різною мірою виявляється у фразеологізмах: кресати з очей блискавиці (294), метати громи і блискавки (96), бушувати як буря (33), грім би його побив! (96), грім його скарай! (96), хай його із землею змісить! (172), потрясати повітря (332), аж у хмари вдарило (500). Семантика «бути про себе високої думки, пихато поводитися» реалізується у таких фраземах: нестися аж до хмар (500), піднестися над хмари (500), не бачити ані землі, ні неба (172), мов не черкаючи землі (172), море по коліна (256), доп'ястися до неба (265), здійматися до неба (265). Значення «несподівано і безслідно зникнути» різною мірою виявляється у фразеологізмах: мов вітер здув (51), мов вітром здуло (51), як вітром змело (51), мов у воду впасти (54), як вода вмила (когось) (54), змести із землі (171), зрівняти із землею (171), рівняти з землею (172), згладитися з лиия землі (226), танути, мов лід на вогні (228), вилетіти в повітря (331).

Синонімічність деяких аналізованих мовних одиниць грунтується на значенні саме лексеми - назви явища природи, наприклад: аж $y$ хмари зайти (500) «здійснити щось нереальне, нездійсненне»; за хмарами (500) «подумки у мріях, відірвано від реального життя»; залітати за хмари та зариватися в хмари (500) «мріяти про щось нереальне, недосяжне»; літати в хмарах та літати в хмари (500) «нереально сприймати дійсність, бути мрійником»; мандрувати поза хмари (500) «мріяти про щось нереальне, недосяжне». Усі пропоновані фразеологізми об' єднані семою «нереальне, відірване від життя».

У синонімічному ряду: небо дарувало (265) «судилося щонебудь комусь»; небо з’єднало (265) «судилося бути разом»; небо зласкавилось (265) «щось склалося сприятливо, хоч для цього начебто не було передумов»; небо ниспослало (265) «щось склалося, здійснилося в житті»; небо пошле (265) «щось або хтось 3'явиться, прийде»; небо судило (265) «щось склалося, здійснилося у когось 
певним чином»; падати з неба (266) «діставатися дуже легко, без труднощів», - об’єднання мовних одиниць відбулося на грунті семи «щось склалося сприятливо з волі вищих сил».

Наведені приклади доводять, що досліджувані фразеологізми яскраво представляють синонімічні відношення у фразеології української мови. Використані у перекладах Миколи Лукаша фразеологічні одиниці 3 компонентом-назвою явища природи, за нашими даними, можуть вступати й в антонімічні відношення.

В. С. Калашник та Ж. В. Колоїз, розглядаючи фразеологічну антонімію, визначили основні критерії встановлення антонімії у фразеології. Так, «фразеологічні одиниці є антонімами, якщо: а) усталені словесні комплекси диференціюються протилежною, контрастною семантикою; б) семантично-цілісне фразеологічне значення усталених конструкцій знаходиться в опозиції «фразеологізм - фразеологізм»; в) усталені конструкції є мовними знаками однієї логічної сутності» $[1$, c. 4]. Фразеологічна антонімія охоплює як структурно однотипні, так і структурно неоднотипні усталені словесні комплекси. За даними фактологічного матеріалу, наявні такі антонімічні пари усталених конструкцій із компонентом-назвою явища природи:

1) структурно однотипні фразеологічні антоніми, що організовані за однаковими фразеологічними моделями і мають компонент, який експліцитно виражає антонімію: мов у воду впасти (54) - як із води (з'явитись) (54); немов крізь землю провалитися (172) - неначе з-під землі вирости (172); небо дарувало (265) - небо не судило (265); нестися аж до хмар (500) - провалитися крізь землю (171);

2) структурно однотипні фразеологічні антоніми, що поєднують компоненти, опозиція яких зовсім не пов'язується 3 лексичною антонімією, а диктується загальною контрастною семантикою: потрясти повітря (332) - мов води в рот набрати (54); проймати морозом (256) - мов пшениця на сониі (353);

3) структурно неоднотипні фразеологічні антоніми, що організовані за різними фразеологічними моделями, проте містять у собі протилежні значення: як риба без води (361) - мічно держатися на землі (172); аж морозом сипонуло поза спиною (256) - море по коліна (256).

Аналіз фактологічного матеріалу дозволяє стверджувати, що семантика фразеологізмів із компонентом-назвою явища природи $€$ дуже різноманітною. Такі фраземи є прикладами багатозначності, синонімії та антонімії усталених конструкцій, а також на їх грунті можна простежити варіативність фразеологічних одиниць. 
До фразеологічних варіантів належать: мов вітром здуло; як вітром змело (51) «хтось або щось раптово, несподівано зникло»; не взятися й за холодну воду; не братися й за холодну воду (53) «нічого не робити, байдикувати»; спалив би вас грім небесний!; грім його скарай!; побив би ӥх грім! (96) «виражає незадоволення ким-небудь»; змести із землі; зрівняти із землею (171) «зруйнувати повністю, знищити вщент»; змітати з лиия землі; знищити з лиця землі; заладитися з лиця землі (226) «знищити повністю»; уритися очима в землю (306); устромити очі в землю; утупити очі в землю (307) «не дивитися прямо на кого-небудь, потупити погляд»; як осіння хмара; як темна хмара (501) «похмурий, невеселий, сумний»; сіяти дощем; посипатися дощем (125) «з'явитися у дуже великій кількості»; небо дарувало; небо зласкавилось; небо ниспослало (265) «щось склалося, здійснилося в житті» тощо.

За нашими даними, наявні й варіанти, що різняться граматичною формою деяких однакових слів (морфологічні): розвіюватися вітром; розвіюватися по вітру (51) «губитися, зникати, пропадати»; літати в хмарах; літати в хмари (500) «нереально сприймати дійсність, бути мрійником»; видові - розлити море сліз; проливати море сліз (256) «дуже гірко плакати»; прихиляти / прихилити небо (266) «робити для когось усе, навіть неможливе»; нестися / піднестися над хмари (500) «дуже високо піднятися».

В. Д. Ужченко та Д. В. Ужченко зазначають, що «при варіюванні фразеологізм залишається самим собою; варіантність - це різні зміни фразеологічних одиниць при іiі тотожності; оболонка фразеологічної одиниці може зазнавати відчутних змін, але загальне значення іiі залишається незмінним; зміни й коливання в лексичній системі відбиваються і в лексемному складі фразеологізму; фразеологічні варіанти можна вважати виявом синонімічності, де відмінності між синонімами зведені до мінімуму; лексичні взаємозаміни в межах фразеологічних одиниць вирізняються доволі відчутною «свободою»: нерідко спостерігається й субституція системно невпорядкованих лексем; чіткої межі між фразеологічними синонімами та фразеологічними варіантами немає» [2, с. 113].

Таким чином, фразеологізми у мові функціонують не ізольовано, а органічно вписуються в мовну систему. Цілісність значення фразеологічних одиниць зумовлює витворення системних відношень, аналогічних лексичним одиницям: полісемія, омонімія, синонімічні, варіантні й антонімічні відношення. Проаналізований фактологічний матеріал засвідчив, що фразеологізми 3 компонентом-назвою явища 
природи, використані у перекладах Миколи Лукаша, можуть вступати між собою у синонімічні та антонімічні відношення, а також яскраво представляють приклади лексичних та формальних варіантів фразем; тоді як омонімічні відношення серед зафіксованих мовних одиниць відсутні.

\section{Примітка}

* Паспортизація ведеться за книгою: Фразеологія перекладів Миколи Лукаша: Словник-довідник / [Уклали О. І. Скопненко, Т. В. Цимбалюк]. - К. : Довіра, 2003. - 735 с.

\section{1.Калаиник В. С. Словник (p) \\ Література}

В. С. Калашник, Ж. В. Колоїз. - [3-є вид., допов.]. - К. : Довіра, 2006. - 349 с.

2.Ужченко В. Д. Фразеологія сучасної української мови: [навч. посібник] / В. Д. Ужченко, Д. В. Ужченко. - К. : Знання, 2007. - 494 с.

3.Череватенко Л. «Сподіваюсь, ніхто не скаже, що я не знаю української мови» [Післямова] / Леонід Череватенко // Фразеологія перекладів Миколи Лукаша: Словник-довідник / [Уклали О. І. Скопненко, Т. В. Цимбалюк]. - К. : Довіра, 2003. C. 711-733. 